\title{
URBANIZÁCIÓ A FEJLŐDŐ ORSZÁGOKBAN: TRENDEK, DIMENZIÓK ÉS KIHÍVÁSOK
}

\author{
(Urbanization in Developing Countries: Trends, Dimensions and \\ Challenges)
}

\section{RICZ JUDIT}

\begin{abstract}
Kulcsszavak:
urbanizációs válság fejlödö országok elsö-városi dominancia óriásvárosi koncentráció

A világ népességének növekedése a következö negyedévszázadban szinte kizárólag a fejlödö országok városaiban fog koncentrálódni. A tanulmány a statisztikák tükrében vizsgálja a városi népesség növekedését, valamint annak városméret szerinti eloszlását 1950-töl 2030-ig. A fejlett országokat használva referenciapontként hat speciális jellemzöjét mutatjuk be a fejlödó országokban zajló urbanizációnak, és kiemeljük az óriásvárosokban való koncentrálódásra irányuló tendenciát. Végül értelmezzük az urbanizációs válságot, és illusztráljuk, mit jelent ez a gazdaságpolitika számára.
\end{abstract}

Számos nemzetközi fejlesztési és pénzügyi intézmény (pl. ENSZ és szakosított szervezetei, Világbank), gyakori politikai viták és médiahírek, publicisztikai írások, söt a forprofit szférában tevékenykedö egyik transznacionális vállalat nemrégiben napvilágot látott kutatása is felhívja a figyelmet a fejlỏdỏ országokban zajló urbanizáció folyamatára, valamint azon belül is a legnagyobb, az ún. mega-városok szerepére (Megacity... 2007). Nézetünk szerint a „,elületes” szemlélő mindezek alapján azonban sok esetben egyoldalúan, máskor pedig egyenesen tévesen értelmezheti a harmadik világban napjainkban is zajló urbanizáció folyamatait, várható trendjeit és következményeit. Mindezen tévhitek tisztázása is adhatná az alapot ahhoz, hogy a szegényebb országok gazdaságainak térbeli mintázatát vizsgáljuk, de erre további okokat is találunk.

Mind a fejlődés-gazdaságtan, mind a regionális és város-gazdaságtani irodalomban viszonylag kevés írás foglalkozik a fejlődő országokban zajló urbanizáció speciális vonásaival, illetve azok jellemzően egy szegmensre, egy okra, egy dimenzióra koncentrálnak, kevés az átfogó, szintetizáló, tényfeltáró írás ebben a témában. Továbbá magyarul alig találunk irodalmat az említett témában, ezért, mint egy másodlagos célunk felhívni a magyar olvasóközönség figyelmét a fejlődő országokban zajló urbanizációs folyamatra, az ebből adódó kihívásokra. Célunk ezáltal, hogy a magyar szakszókincs kialakításához is hozzájáruljunk a vizsgált szakterületen; de a félreértések elkerülése végett sok helyen utalunk majd az eredeti, angol elnevezésre is.

A fejlődő országokra hagyományosan jellemző volt az aktivista fejlesztő állam, és számos gazdaságpolitikai beavatkozás akaratlanul is befolyásolta az urbanizáció folyamatát. A kormányok gyakran anélkül, hogy tudatában lettek volna, maguk is hozzájárultak az urbanizációs válság kialakulásához, melynek tüneti kezelése ma az 
amúgy is szủkös pénzügyi erőforrások terhére történik. Célunk tehát felfedni a gazdasági okok mellett azon politikai okokat is, amelyek kifejezetten a fejlödő országokban elösegítik a legnagyobb városokba való koncentrációt.

Az írás első részében a fejlődő országokban napjainkban is zajló urbanizáció folyamatát vizsgáljuk. Elsőként a számok beszélnek: a stilizált tények tükrében mutatjuk be a folyamatokat, a középpontban az 1950-es évektöl napjainkig tartó időszak áll, majd a várható trendeket tekintjük át a 2030-ig megjelent becslések segítségével. A második fejezetben komparatív megközelítést alkalmazunk, azt vizsgáljuk, hogy mennyiben és miben térnek el a fejlödö országokban bemutatott folyamatok a fejlett országok urbanizációjától. A fejlödő világon belüli regionális eltérésekre utalva látni fogjuk, hogy van legalább egy közös vonás: az óriás városokban való koncentrálódás tendenciája (urban giantism), vagy más szóval az első-városok dominanciája (urban primacy). A következő részben az okokat kutatva azt mutatjuk be, hogy miért is alakulnak ki városóriások a fejlődő országokban. Végül kifejtjük, mit is értünk a fejlödő országokban található urbanizációs válság alatt, és a fejlödés új paradigmája tükrében értelmezzük a válság dimenzióit. Zárásként pedig illusztráljuk, hogy mit is jelent ez a gazdaságpolitikák és a fejlesztéspolitikák számára, azaz néhány normatív megállapítás megfogalmazása is a célunk.

\section{Urbanizáció és a fejlődő országok}

A városi népesség növekedése természetes velejárója a gazdasági fejlődésnek. Az urbanizáció folyamata a mai fejlett országokban viszonylag hosszú idỏ alatt és jóval kevesebb embert érintve zajlott le, mint az a mai fejlődő országokban megfigyelhető. Ezekhez az eltérésekhez hozzáadódnak a mai világgazdaságra jellemző újabb jelenségek, mint a globalizáció és az új kommunikációs és technológiai forradalom kihívásai.

Bár az urbanizáció és a gazdasági növekedés pozitív korrelációja széles körben elfogadott nézet (Henderson 2000; Yusuf 2000), az urbanizáció ennél kiterjedtebb jelenség. A városi népesség növekedése mind magas, mind alacsony jövedelemszintek mellett megfigyelhetö, sőt csökkenö gazdaságokban is jellemzö (Fay-Opal 2000). Továbbá viták zajlanak a szakirodalomban az iparosodás és az urbanizáció viszonyáról is, és az eltérỏ eredmények mögött jellemzöen a vizsgált régiók eltérő aggregáltsági szintje áll. Tény azonban, hogy a fejlődő országok alacsonyabb jövedelmi szintek és az ipar GDP-hez való hozzájárulásának alacsonyabb szintje mellett az urbanizáció magasabb szintjén állnak, mint az hasonló gazdasági fejlỏdési szakaszban a mai fejlett országokra jellemző volt.

$\mathrm{Az}$ urbanizáció alatt sokszor leszükítve a városok népességének növekedését értik, ami része az urbanizációnak, de az több ennél: egy gazdasági, társadalmi és kulturális változást is magában foglaló folyamat. Az urbanizáció összetett folyamatként való értelmezése azonban nehézségekhez vezetne annak mérése során. A statisztikai adatok interpretálása önmagában nem jelzi a lezajló minőségi változásokat. Az urbanizáció egy összetett folyamat, amely mind időben, mind területileg 
állandó változásban van, valamint sokkal több tényezőt tartalmaz, mint amit a statisztikai adatok tükröznek (Cohen 2004).

Ahhoz, hogy a fejlődő és fejlett országok urbanizációs folyamatai közötti eltéréseket felfedjük, elsőként meg kell határoznunk, mely országokat is soroljuk az elöbbi, illetve az utóbbi csoportba. Leginkább egyszerüsége és elterjedtsége miatt $\mathrm{ma}$ is az 1 före jutó GDP alapján rangsorolják az országokat a legtöbb nemzetközi tanulmányban. Tanulmányunkban a UNPD kategóriáira és adataira támaszkodunk, melyek nagyjából megfeleltethetők a világbanki és egyéb besorolásoknak is. A világ országait két csoportja osztjuk: a fejlettebb és a fejletlenebb régiókra (a későbbiekben utalunk a fejlődő világon belüli eltérésekre is). Előbbiek közé soroljuk Észak-Amerikát, Európát, Új-Zélandot, Ausztráliát, Japánt. Míg a fejletlenebb régióba tartozik Ázsia (Japán kivételével), Afrika, Latin-Amerika és a Karibi térség (LAK országok), Mikronézia, Polinézia és Melanézia. Nyilvánvalóan ez egy „durva” kategorizálás, mely leginkább a statisztikai tájékozódást szolgálja, de nézetünk szerint alkalmas a térbeli koncentrálódás legfőbb eltéréseinek felfedésére.

Elsőként a fejlỏdỏ országokban zajló urbanizáció folyamatát mutatjuk be a számok tükrében, komparatív megközelítésben.

\section{A stilizált tények}

Az urbanizációs trendek bemutatásánál leegyszerüsítve a demográfiai megközelítést követjük a statisztikai adatok elérhetöségének megfelelően, bár tudjuk, hogy az ennél sokrétúbb, összetettebb folyamat. Az urbanizáció két dimenzióját tekintjük át: egyrészt a városi népesség arányának növekedését az össznépesség arányában világszinten, valamint regionális bontásban; másrészt a városi népesség megoszlását a különböző méretủ városok között, azaz az urbanizáció városnagyság szerinti mintázatát.

A szakirodalomban eltérő számok találhatók a különböző városméretek közötti határvonalak tekintetében, és nincs általánosan, világszerte elfogadott definíciója annak, hogy mit tekintünk városi területnek (Cohen 2004, 25). Továbbá gondot jelenthet a nemzeti adatszolgáltatások eltérỏ rendszere, valamint az is, hogy a legmegbízhatóbb adatokat a népszámlálások szolgáltatják, melyekre azonban többnyire csupán tízévente kerül sor. Az adatok, idősorok összehasonlithatósága érdekében ebben az írásban, ahol csak lehet, az ENSZ Népességi Osztálya ${ }^{1}$ által kiadott World Urbanization Prospects adataira támaszkodunk (UNPD 2004; 2006), így röviden definiáljuk a tanulmányunkban használt föbb kategóriákat.

Az említett tanulmány a városi népesség megadásánál a nemzeti adatszolgáltatásra támaszkodik. A nemzeti adatszolgáltatások azonban eltérnek egymástól: egyes országok a város saját lakosságát (city proper) a közigazgatási határon belül lakó népesség számával azonositják, míg más országok a városi agglomerációra közölnek adatot. A városi agglomeráció (urban agglomeration) esetében közigazgatási határtól függetlenül a város környékének sürün lakott területeit is figyelembe veszik. Néhány ország esetében az adatok a funkcionális városi tẻrségre, vagy szó 
Ricz Judit : Urbanizáció a fejlődő országokban: Trendek, dimenziók és kihívások Tér és Társadalom 21. évf. 2007/3. 167-186. p.

szerinti fordításban a metropolisz térségére (metropolitan area) vonatkoznak. Ez tágabb az agglomerációs területnél, amennyiben a magváros környezetében az alacsonyabb népsúrüségü, de funkcionálisan a magváros közvetlen befolyása alatt álló településeket is figyelembe veszi. A nemzetközi adatok összehasonlitása során ezen besorolási eltérések is állhatnak a különbségek hátterében, illetve a nemzeti besorolási gyakorlatok is változhatnak az idő folyamán.

A következö évtizedekben a világ népességének növekedése a fejlödő országokban fog koncentrálódni, azon belül is szinte kizárólag ( $98 \%$-ban) a városi népesség növekedése várható (UNPD 2006, 2).

$\mathrm{Az}$ 1. ábra jól szemlélteti, hogy a világ fejlett térségeiben a vidéki népesség 1950 óta fokozatosan és kismértékben csökken, a városi népesség hasonlóan kiegyensúlyozottan változott, de némi növekedést mutat. A fejlődő országokban azonban 2000-ig mind a városi, mind a vidéki népesség eröteljesen növekszik. A fejlődő országokban a 2000-2030 közötti időszakra vonatkozóan azonban a vidéki népesség növekedésének lelassulását, stagnálását jelzik elöre, ugyanakkor a városi népesség közel megduplázódása várható ugyanebben a periódusban. A fejlődő országokban ez adja az urbanizációs válság egyik dimenzióját (I. bővebben a tanulmány utolsó részében).

A fejlődő országokban a városi népesség növekedésének üteme ugyan lassulni fog a következö évtizedekben, de az így is jelentős marad: a 2005-30 közötti időszakban várhatóan 2,2\% lesz, és összesen 1,6 milliárd embert érint majd (UNPD 2006, 3).

\section{1. ÁBRA}

Városi és vidéki népesség növekedése a fejlett és a fejlödő országokban (1950-2030) (Growth of Uban and Rural Population in Developed and Developing Countries [1950-2030])

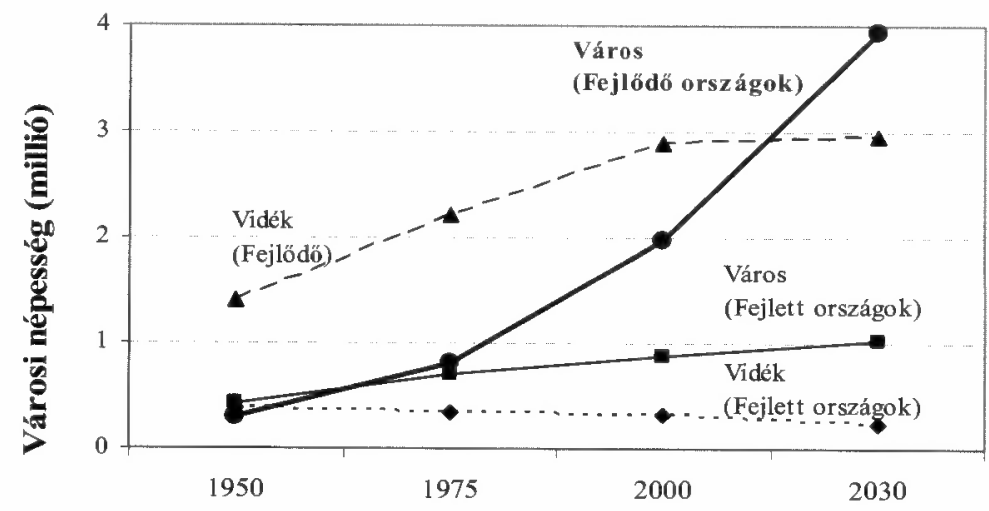

Forrás: Az UNPD (2006) adatai alapján saját szerkesztés.

A 2. ábrán jól látszik, hogy a fejlődő országokban az ötvenes évek óta gyors urbanizálódás zajlott le. A világ átlagában a városi népesség aránya a teljes népesség- 
Ricz Judit : Urbanizáció a fejlődő országokban: Trendek, dimenziók és kihívások

Tér és Társadalom 21. évf. 2007/3. 167-186. p.

TÉT XXI. évf. 2007 - 3

Kitekintö

171

hez viszonyitva az 1950-es 30\% alatti szintröl indulva 2005-re elérte az 50\%-ot. Az elörejelzések szerint ez a folyamat folytatódni fog, és 2030-ra $60 \%$ feletti lesz a városi népesség aránya.

\section{2. ÁBRA}

A városi népesség arányának változásai a világban (1950-2030)

(Changes in the Share of Urban Population in the World [1950-2030])

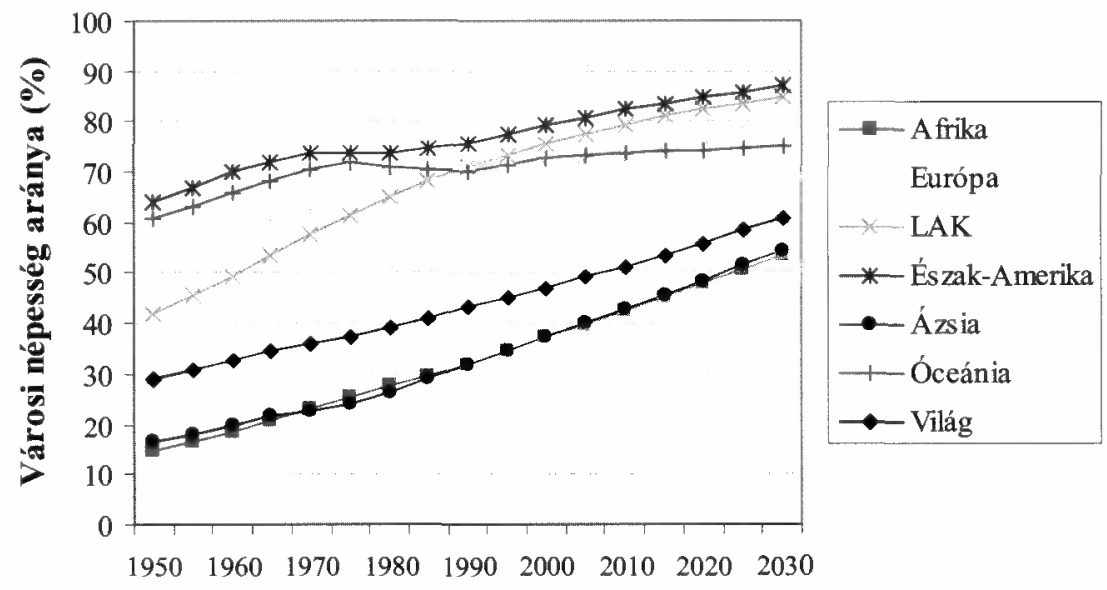

Forrás: Az UNPD (2006) adatai alapján saját szerkesztés.

Ugyanakkor, ha régiónkénti bontásban nézzük az adatokat, jól látszanak a különbségek a fejlett és fejlődó országok között, valamint ez utóbbi csoporton belül is. A fejlettebb térség (Európa, Észak-Amerika és Óceánia) már az ötvenes években erősen városiasodott $-50 \%$ felett volt a városi népesség aránya, ami 2000 -ig jelentös mértékben tovább növekedett elérve a 75-80\% körüli szintet. Ezzel párhuzamosan azonban a növekedési ütem lassult, és 2030-ig már csupán 7\%-os növekedés várható.

A fejlődő országokon belül kiemelkedik a latin-amerikai és a karibi térség (LAK országok), ahol az urbanizáltság már az ötvenes években magas, $40 \%$ feletti értéket mutatott, majd 2000-re elérte a fejlett országok átlagát (75\%), és 2030-ra az előrejelzések szerint meg is haladja azt. A fejlődó országok másik két térségét tekintve láthatjuk, hogy Afrika és Ázsia (Japán kivételével) közel azonos urbanizáltsági szinten álltak az ötvenes években, 15-18\% volt a városi népesség aránya. Azóta is gyakorlatilag egyuitt mozognak a két térség mutatói. Egy fél évszázad alatt e térségekben duplájára nőtt a városi népesség aránya, és az ezredfordulón meghaladta a 35\%-ot. A következő 25-30 évben bár valamelyest lassulni fog a városi népesség növekedési üteme, világviszonylatban azonban továbbra is gyors lesz, és 2030-ra mind Ázsiában, mind Afrikában a városi népesség aránya meghaladja majd az 50-55\%-ot.

Érdemes felhívni a figyelmet még egyszer a kategorizálás durva egyszerüsítéseire, ugyanis az egyes térségeken belül is éles eltérések figyelhetők meg (pl. ÉszakAfrika és Fekete-Afrika országai között), melyek bemutatása azonban meghaladja jelen írás kereteit. Nézetünk szerint azonban a fent bemutatott regionális összeha- 
sonlítás jól szemlélteti az elmúlt 50 évben tapasztalható urbanizációs folyamatok jelentőségét a fejlődő régiókban. A 2. ábrán láthattuk a latin-amerikai robbanásszerủ városi népességnövekedést, mely azonban az ezredfordulóra „kifulladt”, és lényegesen lassabb ütemben folytatódik. Ezzel szemben az afrikai és ázsiai urbanizáció lassabb szintről indult a múlt század közepén, de töretlenül, sőt valamelyest gyorsabb ütemben való folytatódása várható a jelzett időszak végéig, 2030-ig.

$\mathrm{Az}$ általános trendek felvázolása után tekintsük át a bemutatott városi népességnövekedés megoszlását a különböző méretü városok szerint. Az UNPD (2004; 2006) a már említett tanulmányaiban nagyvárosnak (large cities) nevezi az 5 millió vagy annál több lakossal rendelkezö városokat, ezek közül a 10 milliós vagy annál nagyobb népességúek a mega-városok (mega-cities). További adatok találhatók az 1 millió vagy annál nagyobb lakosság számú közepes és nagy városokra, valamint az 500 ezer fö alatti településekre, melyeket kisebb városi településeknek (smaller urban settlements) neveznek. Ezt a besorolást követjük a jelen tanulmányban is, azzal a megjegyzéssel, hogy a szakirodalomban esetenként mega-városnak nevezik a 4-5 millió feletti lakossal rendelkező városokat is, illetve az alacsonyabb kategóriáknál is eltérések tapasztalhatók.

Nézetünk szerint azonban a későbbiekben kifejtendő urbanizációs válság vizsgálatához jó támpontot adhat a már említett három kategóriából álló besorolás, mely megkülönbözteti a vidéki, kisvárosi és nagyvárosi területeket. Még nincs bevett gyakorlat ez utóbbi megközelítésre, de véleményünk szerint ekkor a nagyobb közepes városokat is az utóbbi kategóriába sorolhatnánk, azaz nagyvárosi területnek tekinthetjük az 1 milliónál népesebb városokat is, amennyiben azok esetenként hasonló kihívásokat állítanak a központi és helyi kormányzat, a gazdaság szereplői, valamint a lakosság elé, mint más nagyobb városok ${ }^{2}$.

Az 1. táblázat a városi népesség eloszlását mutatja a különböző méretủ városokban 1975-2015 között, továbbá tartalmazza az eltérő méretú városok számának alakulását is. Nézzük elsőként a 10 millió vagy afeletti lakosságszámú megavárosokat, melyek jelentös növekedésen mentek át az elmúlt évtizedekben, mind lakosságszámuk, mind a világgazdaságban betöltött jelentőségük alapján ${ }^{3}$. 1975-ben még csak négy mega-város volt a világban, 2000-ben már 18, és a becslések szerint 2015-re 22-re nő a számuk. Ezek közül 1975-ben csak kettő, míg 2000-ben 13 volt a fejlődô országokban, és 2015-re újabb három szegényebb országbeli város népessége fogja átlépni a 10 milliós határt. Az 1975-2000 között a világ városi népessége 2,5\%-kal növekedett, a mega-városok népessége több mint kétszer ilyen ütemben, 5,4\%-kal. Még látványosabb a növekedés, ha a népességszámokat tekintjük: 53 millió fởởl 240 millióra nőtt a mega-városokban lakók száma világviszonylatban. A fejlödő országban ugyanezek a mutatók még meggyőzőbbek: 22 millióról 154 millióra nőtt a legnagyobb városok lakossága. Ugyanakkor megjegyzendő, hogy ez a növekedés nagyobbrészt az ebben az időben mega-várossá váló településeknek tudható be. Az összes városi népesség arányában azonban mindössze $8-10 \%$-ot tesz ki a megalopoliszok lakosainak aránya. 


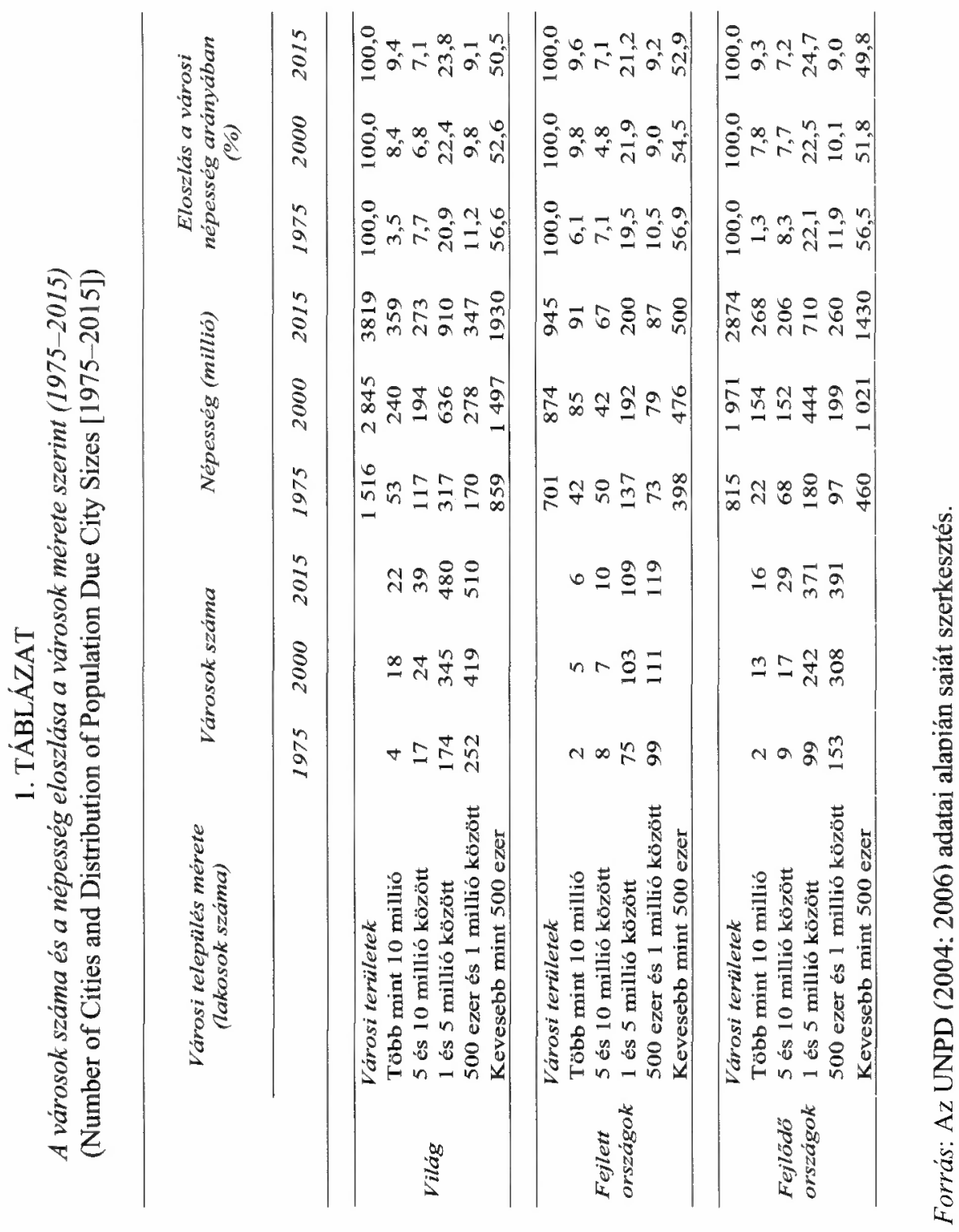


Megállapíthatjuk tehát, hogy bár látványos növekedést mutattak fel a fejlődő országok legnagyobb városai az elmúlt fél évszázadban, túlzottak azok a félelmek, amelyek szerint a világ mega-városai robbanásszerủen növekednek, illetve hogy a világ városi népességének növekedése a mega-városokra koncentrálódik. A tanulmány következỏ részében foglalkozunk részletesen azzal a témával, miért is tekintjük mégis a mega-városokat az urbanizációs válság elsődleges helyszíneinek.

A világ nagyvárosaiban, az 5 és 10 millió közötti lakosságszámot felmutató településeken ugyancsak jelentős változások zajlottak le. 1975-ben a világon 17 város tartozott ebbe a kategóriába, és ez a szám 2000-re 24-re nött, ami annak a figyelembevételével, hogy ebben a periódusban 14 város emelkedett fel ebből a kategóriából a mega-városok közé, nem jelentéktelen növekedés. 2015-ig további 15 város esetében várható, hogy átlépi az 5 millió fös népesség-küszöböt, és ezek közül 12 a fejlődő országokban található. Éppen az említett városok mega-várossá növekedése miatt 1975 és 2000 között a fejlődő országokban, arányaiban csökkent a nagyvárosok súlya az össznépességhez viszonyítva, de 2015-ig újabb növekedés várható. 2000-ben 194 millióan éltek a világon az említett nagyvárosi kategóriában, és több mint háromnegyedük a fejlỏdő világ népességéhez tartozott.

Az 1-5 millió közötti lakosú városok száma több mint kétszeresére nőtt a vizsgált időszakban világviszonylatban, és ez a növekedés is legnagyobb részt a fejlődő országokban zajlott. Ott ugyanis 1975-ben még kevesebb mint 100 város tartozott az említett kategóriába, 2000-re számuk meghaladta a 240-et. A népességszámokat tekintve is kimagasló a fejlődô régió dominanciája: 444 millióan éltek ezekben a közepesen nagy városokban, szemben a fejlettebb régió 192 millió fös értékével.

Mind világszinten, mind a fejlödő országok tekintetében a kis és közepes méretú városokban (az 1 millió fớ alatti településeket soroljuk ide) koncentrálódik a városi népesség jelentôs hányada, több mint 60\%-a, közel 1,8 milliárd ember. Ugyanakkor 2015-ig az e kategóriában koncentrálódó városi népesség arányának csökkenése várható világ szinten is, de a fejlődő országok esetében még inkább.

Mindezek alapján elmondhatjuk, hogy 1975 óta a fejlődỏ országok városi struktúrájában eltolódást figyelhetünk meg az egyre nagyobb városok irányába, és ez a trend bár lassabban, de várhatóan folytatódni fog. Hangsúlyozzuk, hogy a legnagyobb városokban való koncentrálódás a statisztikák alapján is inkább a fejlődỏ országokra jellemző, mint a fejlett világra. Az 1, az 5 és a 10 millió feletti lakosságot tömörítö városok is lényegesen nagyobb arányban koncentrálódnak a fejlődő országokban, és ennek megfelelöen az abszolút számok tekintetében is nagyobb tömegeket érintenek, mint a fejlettek esetében. A 2. táblázatban látható, hogy a világ 20 legnagyobb városából 15 a fejlödỏ országokban található, és ezek között vannak a világ leggyorsabban növekvő mega-városai is (Delhi, Jakarta, Dhaka, Lagosz). 
Ricz Judit : Urbanizáció a fejlődő országokban: Trendek, dimenziók és kihívások Tér és Társadalom 21. évf. 2007/3. 167-186. p.

TÉT XXI. évf. 2007

Kitekintö 175

\section{TÁBLÁZAT}

A világ legnagyobb városainak népessége és népességnövekedése (1975-2015) (Population and Growth of the World Largest Cities [1975-2015])

\begin{tabular}{|c|c|c|c|c|c|c|c|}
\hline \multirow{2}{*}{\multicolumn{2}{|c|}{ Városi agglomeráció* }} & \multicolumn{4}{|c|}{ Népesség (millió) } & \multicolumn{2}{|c|}{$\begin{array}{l}\text { Attagos éves növe- } \\
\text { kedési ráta (\%) }\end{array}$} \\
\hline & & \multirow{2}{*}{$\frac{1975}{26,6}$} & \multirow{2}{*}{$\begin{array}{r}2000 \\
34,4\end{array}$} & \multirow{2}{*}{$\begin{array}{r}2005 \\
35,2\end{array}$} & \multirow{2}{*}{$\begin{array}{r}2015 \\
35,5\end{array}$} & \multirow{2}{*}{$\begin{array}{c}1975- \\
2005 \\
0,93\end{array}$} & \multirow{2}{*}{$\begin{array}{l}2005- \\
2015 \\
0,08\end{array}$} \\
\hline 1 & Tokió & & & & & & \\
\hline 2 & Mexikóváros & 10,7 & 18,1 & 19,4 & 21,6 & 1,99 & 1,05 \\
\hline 3 & New York & 15,9 & 17,8 & 18,7 & 19,9 & 0,55 & 0,60 \\
\hline 4 & São Paulo & 9,6 & 17,1 & 18,3 & 20,5 & 2,15 & 1,13 \\
\hline 5 & Mumbai (Bombay) & 7,1 & 16,1 & 18,2 & 21,9 & 3,15 & 1,84 \\
\hline 6 & Delhi & 4,4 & 12,4 & 15,0 & 18,6 & 4,08 & 2,12 \\
\hline 7 & Shanghai & 7,3 & 13,2 & 14,5 & 17,2 & 2,28 & 1,72 \\
\hline 8 & Kalkutta & 7,9 & 13,1 & 14,3 & 17,0 & 1,98 & 1,73 \\
\hline 9 & Jakarta & 4,8 & 11,1 & 13,2 & 16,8 & 3,37 & 2,41 \\
\hline 10 & Buenos Aires & 8,7 & 11,8 & 12,6 & 13,4 & 1,20 & 0,65 \\
\hline 11 & Dhaka & 2,2 & 10,2 & 12,4 & 16,8 & 5,81 & 3,04 \\
\hline 12 & Los Angeles** & 8,9 & 11,8 & 12,3 & 13,1 & 1,07 & 0,63 \\
\hline 13 & Karachi & 4,0 & 10,0 & 11,6 & 15,2 & 3,56 & 2,67 \\
\hline 14 & Rio de Janeiro & 7,6 & 10,8 & 11,5 & 12,8 & 1,39 & 1,07 \\
\hline 15 & Oszaka-Kobe & 9,8 & 11,2 & 11,3 & 11,3 & 0,45 & 0,04 \\
\hline 16 & Kairó & 6,4 & 10,4 & 11,1 & 13,1 & 1,82 & 1,66 \\
\hline 17 & Lagosz & 1,9 & 8,4 & 10,9 & 16,1 & 5,84 & 3,94 \\
\hline 18 & Peking & 6,0 & 9,8 & 10,7 & 12,9 & 1,91 & 1,82 \\
\hline 19 & Manila & 5,0 & 10,0 & 10,7 & 12,9 & 2,53 & 1,90 \\
\hline 20 & Moszkva & 7,6 & 10,1 & 10,7 & 11,0 & 1,12 & 0,34 \\
\hline
\end{tabular}

* A városi agglomerációk a 2005-ben elért méretük alapján vannak rangsorolva.

** Az agglomerációs térség Los Angelesen kívül tartalmazza Long Beach és Santa Ana területeit is.

Forrás: Az UNPD $(2006,21)$ alapján saját szerkesztés.

\section{A fejlödő országok urbanizációs folyamatának jellemzöi}

Mielőtt rátérnénk a fejlődő országok legnagyobb városaiban való koncentrálódás és annak következményeinek a vizsgálatára, tekintsük át röviden a világ fejlettebb és fejletlenebb régióiban zajló urbanizációs folyamatok megkülönböztető jegyeit.

Az első és legkézenfekvóbb eltérés az idoozítés (timing), azaz, hogy a fejlett országokban az urbanizáció jellemzően a 19. században kezdődött és a 20. század elsó felében érte el a leggyorsabb ütemet, addig mindez a fejlődỏ világban többnyire a 20. század második felére tehető, és napjainkban is zajlik. A világgazdaság egyre fokozódó integrációja, az ún. globalizációs folyamatok és az új információs és kom- 
munikációs technológiák hatására kialakuló változások eltérő kontextust jelentenek a fejlődö országok számára, és ezek megjelennek azok térbeli mintázatában is.

Második jellemzőként emlitettük a városi népesség növekedési ütemét (pace), amely a fejlödő országokban kétségkívül gyorsnak nevezhetö: 1950 és 1975 között a városi népesség aránya évente 3,91\%-os, míg 1975-2000 között 3,55\%-os növekedést „produkált”, 2030 -ig további 2,29\%-os éves növekedést jelez elöre az ENSZ Népességi Osztálya (UNPD 2004, 3). Ezzel szemben a fejlett országokban 1950-75 között 2,0\%-os, 1975-2000 között 0,91\%-os növekedés volt tapasztalható, míg 2000-2030 között a városi népességnek csupán 0,47\%-os gyarapodása várható. Ugyanakkor, ha a jelenben zajló, a fejlődő országokat érintő térbeli átstrukturálódást a fejlett országok 19. század végi és 20 . század eleji folyamataival vetjük öszsze, nyilvánvalóvá válik, hogy az hasonló ütemben folyt (Cohen 2004, 32).

Harmadikként az abszolút számokat (scale) vizsgálva megállapíthatjuk, hogy míg a fejlett országok városi népessége jelenleg 900 millió fö, és 2030-ig 1 milliárd fö körülire nő, majđ ott stagnál, addig a fejlöđö országok városi népessége 2003-ra átlépte a 2 milliárdos küszöböt és az UNPD (2006) elörejelzések szerint 2030-ig megközelíti a 4 milliárdot. A városi népesség abszolút számokban vett növekedése tehát történelmileg is egyedi jelenség, melynek a hátterében az áll, hogy a használt besorolás szerint a világ népességének 3/4-e a fejlödỏ országokban él, és ami még fontosabb, hogy a népesség növekedési üteme sokkal gyorsabb a kevésbé fejlett régiókban.

Negyedik jellemzőként említhetjük Brutzkus (1975) és Puga (1996) megállapítását, mely szerint a fejlödő országokban zajló urbanizáció területi mintázata és a városok méretei eltérnek a fejlett országok tapasztalatai alapján megfogalmazott várakozásoktól. Ez az említett abszolút számokbeli eltérésekre is visszavezethető: 2030-ig mintegy 2 milliárddal nő a fejlődő országokban a városi népesség száma. Ennek tudatában nem meglepỏ sem a nagyvárosok, városóriások számának növekedése, sem a városok méretének növekedése. A városóriásokra és az elsö-városi koncentrációra, valamint a „centralizált urbanizációra" a későbbiekben még kitérünk.

Az ötödik eltérés, hogy a gazdasági fejlödés különböző szintjei mellett zajlott, illetve zajlik a népesség városokban való koncentrálódásának növekedése a fejlett és a fejlöđö országokban. Konszenzus van arról a szakirodalomban, hogy alacsonyabb GDP/fố szintek mellett a fejletlenebb régiók magasabb urbanizáltsági szintet értek el (Yusuf 2000; Todaro-Smith 2003, 314), továbbá föként Afrikában figyelték meg az urbanizáció folytatódását gazdasági növekedés hiányában, recesszió ideje alatt is (Fay-Opal 2000). Hasonló összefüggéseket lehet találni az iparosodás szintjét, valamint az ipari foglalkoztatottak arányait tekintve is, azaz itt is jelentös a lemaradásuk a fejlődő országoknak.

Hatodikként említhetjük, hogy számos esetben a kedvezőtlenebb természeti adottságok (pl. Chile, Egyiptom a földrajzi adottságok miatt is a világ legkoncentráltabb városi struktúráival rendelkezik), valamint a történelmi, gyarmati hagyaték ${ }^{4}$ is olyan megkülönböztetö jegyek, amelyek tipikusan a fejlödỏ országokra jellemzóek (Kasarda-Crenshaw 1991). 
Az eltérö történelmi, demográfiai és gazdasági kontextusokról már esett szó az időzítés, ütem, abszolút mérték vizsgálatánál, valamint a gazdasági, strukturális tényezőkkel való kapcsolat bemutatásánál. Hamer és Linn $(1987,1255)$, valamint Cohen $(2004,27)$ is utalnak az eltérő globális kontextus szerepére, melyet itt az utolsó megkülönböztető jegyként említünk. Míg az előbbi szerzőpáros az új hazai vagy külföldi vándorlási lehetőségek beszükülésére utal, addig az utóbbi szerző a transznacionalizáció, az ún. sokarcú globalizáció folyamatait emeli ki, különösen a nyitott gazdaságok erőteljesebb beágyazódottságát a világgazdasági folyamatokba. Kasarda és Crenshaw (1991) is hasonló változásokra utal, amikor az eltérö technológiai fejlettségi szintet, az eltérő életvitelt és az átalakult termék-, szolgáltatás- és tőkepiacok müködését, valamint a globális versenyt emeli ki. Továbbá ugyancsak hangsúlyozzák, hogy a fejlett országok esetében a nemzetközi vándorlás fontos elszívó erőként jelentkezett, mely csökkentette a városokra nehezedő népességnövekedés nyomását. Ez az „egérút”, azaz az emigráció választása a fejlödő országok esetében nem vagy lényegesen kisebb mértékben, illetve nem legális módon jelent lehetőséget.

$\mathrm{Az}$ elöző érveléshez részben kapcsolható a hagyományos vidék-város megkülönböztetés átalakulása. Az új info-kommunikációs technológiák, a tömegmédia és számos egyéb „globalizációs” tényező az életmódok konvergenciájának irányába hat (de természetesen a homogenizáló hatások mellett a globalizációnak vannak diverzifikáló hatásai is, melyekre itt nem térünk ki). Ezek alapján a vidéki és a városi életvitel közötti különbségek számos esetben csökkenek, vagy átalakulnak. Ugyanakkor már itt előre utalunk arra, hogy gyakran jobban hasonlít egy falusi és egy kisvárosi háztartás életvitele, életmódja egymásra, mint a kisvárosi és a nagyvárosi háztartásoké. Részben ez adja majd az újfajta megkülönböztetések, új kategóriák szükségességét (Epstein-Jezeph 2001).

Mindezek ellenére hangsúlyozzuk, hogy a fejlödő országokban megfigyelhető urbanizáció nem annak gyors üteme miatt tér el alapvetően a fejlett országok tapasztalataitól. Jellemzỏen a városi népesség gyors növekedésének hátterében az áll, hogy nagyon alacsony annak részesedése az ország össznépességéből. De ahogy ez az arány nö, úgy a városi népesség növekedési üteme is lassul. Megfigyelhetjük, hogy jelentős eltérést jelent a városi népesség növekedésének abszolút mértéke, valamint az urbanizáció térbeli mintázata. A továbbiakban az utóbbival foglalkozunk részletesebben.

\section{Elsö-városi koncentráció (urban primacy) versus óriásvárosi koncentráció (urban giantism)}

Bár a mega-városokban és a nagyobb (5 millió fö feletti) városokban való koncentrációt már bemutattuk, érdemes kitérni egy ezzel részben átfedésben lévő, de gyakran külön tárgyalt jelenségre: az adott ország legnagyobb, ún. első-városában való koncentrálódásra (urban primacy). Ez alatt a város-gazdaságtani és fejlődésgazdaságtani irodalomban azt értik, ha egy ország egy vagy két városa „,abnormálisan" nagy az ország többi városához viszonyítva (eredetileg Jefferson [1939] hasz- 
nálta ezt a jelzőt 1939-es alapcikkében). A fejlỏdő országokra tipikusan jellemzö centralizált urbanizáció további megkülönböztető jegye lehet az adott ország népességének a legnagyobb városban, esetenként városaiban való erőteljes koncentrálódása. A leggyakoribb, hogy a legnagyobb város egyúttal a fỏváros is, de egyes országokban ez a gazdasági elit központja, sőt esetenként nem egy első-város, hanem több aránytalanul nagy város dominálja a városi struktúrát (pl. Brazília).

Számos szerzö (Puga 1996; Venables 2005) szerint az első-városi koncentráció túlnyomórészt a fejlődő országokra jellemző, a WDI és a WUP 2005 (UNPD 2006) adatai alapján ez a nézet nem tủnik teljesen alátámaszthatónak.

A WDI alapján a közepes jövedelmú és az olajexportáló országok esetében a legmagasabb az első-városok dominanciája. Az előbbi a williamsoni (1965) hipotézist tünik alátámasztani, mely szerint a gazdasági fejlődés folyamán eleinte alacsony szintủ a gazdasági tevékenységek koncentrációja, majd ez fokozatosan növekszik, és egy bizonyos fejlettségi szint elérése után újra csökken. Utóbbi, az olajexportáló országok esete pedig a politikai gazdaságtani megközelítéssel is magyarázható, mely szerint az elsö-városi koncentrációt elösegíti a diktatórikus, instabil állami hatalom, melyet tovább ronthat a pontszerủ erőforrások révén kialakuló nyersanyag-átok kialakulása.

A WUP (UNPD 2004) adatai alapján érdemes azonban felhívni a figyelmet arra, hogy az első-városi dominancia, melyet többnyire az első-város népességének az összes városi népességhez viszonyított arányával mérnek, magas lehet viszonylag kisméretủ első-város esetében is. Ez bekövetkezhet, ha kis népességszámú országról van szó, illetve ha az adott országban a városi népesség aránya nagyon alacsony. Továbbá jellemzően nỏ az elsỏ-városi dominancia a politikai konfliktusokkal, háborúkkal sújtott országokban. Ezek az országok, illetve kormányzataik azonban más jellegü kihívásokkal szembesülnek a városi koncentrálódás tekintetében, mint a hatalmas, mega-városok által dominált országok. Azaz, ahogy Kasarda és Crenshaw (1991, 472) fogalmaz, az igazi problémát nem elsösorban az elsö-városi dominancia (urban primacy) jelenti, hanem az óriási városokban való túlzott koncentráció (urban giantism). Sok esetben azonban a két jelenség együtt lép fel, azaz az adott ország legnagyobb, ún. elsö városa egyben mega-város is, vagy legalábbis nagyváros a korábbi besorolásunk alapján, és ekkor a két probléma egybeesik. Emiatt a szakirodalomban gyakran keveredik az elnevezések használata és a jelenségek vizsgálata is.

\section{Az óriásvárosi koncentráció (urban giantism) kialakulásának okai}

A gazdasági tevékenységek térbeli koncentrálódását hagyományosan (Marshall (1890 [1938] nyomán) az agglomerációs elönyökre vezetik vissza. Ezek a földrajzi közelségből származó pozitív externáliák, túlcsorduló hatások (mint pl. tudásáramlás) a nagy munkapiacból származó elönyök, valamint a nagy helyi piacokon jelentkező előre és visszacsatolások következtében sarkallnak a koncentrálódásra. Ugyanakkor az immobil tényezők, az egyre növekvő ingatlanhasználati díjak és egyéb nega- 
Ricz Judit : Urbanizáció a fejlődő országokban: Trendek, dimenziók és kihívások

Tér és Társadalom 21. évf. 2007/3. 167-186. p.

tív externhatások (túlnépesedés, zsúfoltság) a koncentráció ellen hatnak. Ezáltal egy tökéletes világban az urbanizációnak van egy optimális mértéke, mely a centripetális (koncentráció irányába ható) és centrifugális (szétszóródás irányába ható) erők eredője révén alakul ki, és ahol a társadalmi marginális elönyök és a költségek megegyeznek. A város-gazdaságtanban viszonylag kiterjedt irodalma van az optimális városi méretek vizsgálatainak. Henderson (1974) nevéhez füződik az optimális városméret elméletének megalkotása, melyre itt részletesebben nem térünk $\mathrm{ki}^{5}$.

Ezzel a nézettel szemben hívja fel Capello és Camagni (2000) a figyelmet arra, hogy nem az optimális, hanem a hatékony városméret a releváns kérdés. Ez utóbbi a városi ágazatok diverzifikációjának vagy specializációjának, valamint egyéb adottságoknak is a függvénye. Az említett szerzőpáros hangsúlyozza továbbá, hogy a hatékonynál kisebb városméretből származó hatékonyságveszteség nagyságrendekkel meghaladhatja a túlzott méretből származó veszteségeket. Itt azonban csak a gazdasági hatékonyságot veszik figyelembe. Ezzel a nézettel szemben érvelünk a gazdasági és társadalmi hatékonyságok eltéréseinek jelentősége mellett, valamint utalunk a fejlődés tág, környezettel kompatibilis emberi elörehaladásként való értelmezéséből adódó különbségekre, melyeket a tanulmány utolsó részében fejtünk ki bővebben.

A gazdasági hajtóerök a fokozódó globalizáció és az ủj információs és kommunikációs technológiák következtében egyre inkább teret nyerỏ újgazdaság hatására részben átalakulnak. Az agglomerálódás új logikája (Ricz 2007) értelmében a legversenyképesebb, legjövedelmezőbb gazdasági tevékenységek a világ legnagyobb városaiban koncentrálódnak, és közvetlen környezetükböl részben kiszakadva globális szinten integrálódnak. ${ }^{6}$ Sassen (2002) nevéhez füzödik ezen átalakulás legnagyobb városokra való hatásainak és a globális városhálózatok megjelenésének vizsgálata. Ez ismét párhuzamba állítható a dichotóm térbeli megkülönböztetések elavulásával, amennyiben lényeges eltérések figyelhetők meg a kis és közepes városi területek, valamint a legnagyobb városok között.

Puga (1996) hívja fel a figyelmet az öngerjesztő folyamatok és a bennragadás (lock in) jelenségének jelentőségére, amennyiben a megváltozott globális környezetben a fejlödő országok legnagyobb városainak dominanciája tendenciálisan növekszik, szemben a fejlett és kifejezetten európai városi struktúrákkal, melyek kialakulása jóval korábbra datálható, és melyekre inkább a kiegyenlítődés felé való elmozdulás a jellemzö.

A legnagyobb városokban való koncentrálódás hátterében a hagyományos és az új gazdasági hajtóerỏkön kívül más tényezök is állnak. Számos szerzỏ hívja fel a figyelmet arra, hogy a fejlődő országokban nem elsősorban piaci erők vagy modern technológiák állnak az óriásvárosi koncentrációk hátterében, hanem a különböző fejlesztési stratégiák, gazdaságpolitikák. Ez átvezet minket a politikai tényezők vizsgálatához, melyek a központi hatalom közelében való letelepedésre ösztönöznek.

A közszolgáltatások elosztását a nagyobb érdekcsoportok hatására aránytalan mértékben a nagyvárosokba koncentrálja a kormányzat. A probléma felerősödhet, ha gyenge vagy foglyul ejtett a központi állam, illetve ha a kisebb városok nem rendelkeznek kellő autonómiával, érdekérvényesítö képességgel. Ezt fokozhatja a 
centralizált állami berendezkedés, illetve annak hagyománya. Ezeket általánosan városi torzításoknak (urban bias ${ }^{7}$ ), a fövárosok esetében első-városi torzításoknak (first city bias) nevezzük.

A politikai gazdaságtani és a fejlödés-gazdaságtani irodalom a gazdasági ösztönzök mellett kiemeli tehát a politikai hajtóeröket, de szerepet kapnak a gazdaságpolitikák, a történelem és a földrajz is. Ez utóbbiak a „hub and spoke” modellnek megfelelően a kedvező földrajzi adottságok, a gyarmati múlt és a fizikai infrastruktúra következtében vezetnek az óriásvárosi koncentrációhoz. Krugman (2000) hangsúlyozza továbbá az importhelyettesítỏ iparosítás hatását, amely az alacsony nemzetközi kereskedelmi szint mellett, a belső piacon a szállítási költségek minimalizálása révén az egy városba való koncentrációt erösíti; ördögi kört alkotva a nagy piac további termelöket vonz, mely további piacnövekedést eredményez.

Ades és Glaeser (1995) az instabil politikai diktatúrák hatását emelik ki, amelyekben az első-városi népesség aránya (37\%) messze meghaladja a stabil demokráciában találhatót ( $23 \%$ ), és érvelésük szerint ennek oka, hogy a diktatúrákban ,kenyér és cirkusz" kell a népnek. Henderson (2002) számításai szerint pedig azok az elsôvárosok, amelyek egyben a politikai hatalom központjai is (azaz fövárosok), jellemzóen 25\%-kal nagyobb népességet tömörítenek, mint nem föváros társaik. Végül politikai gazdaságtani megközelítésben a politikai hatalom közelében különösen előnyös a letelepedés a gyenge jogállam (rule of law), burjánzó korrupció és a kialakuló járadékvadászat magatartás miatt.

A fejlödő országokban a fenti okok általában egymást erősítve vezettek a városóriások kialakulásához, azaz mikro-szinten jelentkeztek ezek az ösztönzők, és önerősítő folyamatok alakultak ki (ezeket modellezi az új gazdaságföldrajz irányzata).

Tanulmányunkban azonban nem bocsátkozunk további elméleti fejtegetésekbe, hanem a legfontosabb következményeket vizsgáljuk, amelyek a fejlödő országokban megfigyelhetô centralizált városi struktúrákból adódnak. Mindeközben szem előtt tartjuk, hogy a gazdasági fejlettség alacsonyabb szintje mellett több, nagyobb és gyorsabban növekvő nagyváros jelenléte jellemző a szegényebb országokban, mint a fejlett világban.

\section{Miért probléma az óriásvárosi koncentráció (urban giantism)?}

Az eddigiekben bemutattuk, hogy a fejlődỏ országokra tipikusan jellemző a legnagyobb városokban való koncentrálódás, azaz, ahogy neveztük, az óriásvárosi koncentráció. Ebben a fejezetben azt nézzük meg közelebbről, hogy miért jelent problémát ez a jelenség.

Első megközelítésben két részre lehet osztani a problémát: magából a városméretből adódó kihívásokra, valamint a kormányzat nem megfelelő menedzsment képességeiböl és kapacitásaiból adódó kudarcokra. Számos szerző szerint a városméret önmagában nem jelent problémát a gazdasági hatékonyság szempontjából ${ }^{8}$, de belátják, hogy a társadalmi fejlődés és a fenntartható természeti környezet tekinteté- 
ben maga az óriási földrajzi koncentráció is gondot jelenthet. Nézetünk szerint azonban közép- és hosszú távon ez utóbbiak visszahatnak az elöbbire, azaz a gazdasági növekedésre és fejlődésre is.

Hamer (1994, 175-177) szerint nem a városméret maga jelent problémát, hanem annak a gazdasági fejlettség szintjéhez és a menedzsment kapacitásokhoz viszonyított aránya, valamint a népességnövekedés üteme. Ennek értelmében a fejlett Japánban található közel 35 milliós Tokió agglomerációs térsége kevésbé jelent fejlödési tehertételt, mint az ,alig” 10 milliós nigériai Lagosz. Tokió 35 millió fős városi koncentrációja az egy före eső jövedelem közel 35 ezer dolláros szintjével, valamint megfelelö helyi kormányzati és menedzsment képességekkel és kapacitásokkal párosul, továbbá gyakorlatilag nincs informális szektor és a nullához közelít a város növekedési üteme. Ezzel szemben bár Lagosz népessége 2005-ben épphogy elérte a mega-városi kategória alsó határát, az a gazdasági és társadalmi fejlődés tekintetében lényegesen komolyabb kihívásokat jelent Nigéria számára. A lagoszi népesség növekedési üteme 1975-2005 között éves átlagban megközelítette a 6\%-ot, és a következö évtizedben is $4 \%$ körüli éves növekedés várható. Mindez igen alacsony gazdasági fejlettségi és jövedelmi szint, és ugyancsak rendkívül alacsony kormányzati és menedzsment képességek és kapacitások mellett valósult meg. A halmozódó anomáliákat jól jelzi a közel 70\%-os informális foglalkoztatottság (GUO 2007).

Ezen folyamatok közvetlen következményei, hogy a közszolgáltatások, lakhatás és közlekedés kínálata nem képes lépést tartani a növekvő kereslettel, mint ahogy a formális munkaerőpiac sem képes felszívni a városba áramló tömegeket. Innen már csak egy lépés az informális szektor megjelenése és növekedése, a magas és növekvő szintü alulfoglalkoztatás és munkanélküliség, valamint a nyomornegyedekben való koncentrálódás és a szegénység kiterjedése. A természetes környezet eltartó képességét is meghaladja ez a nagyfokú földrajzi koncentráció, melynek jelei a nemzetközi elöírásokat sokszorosan meghaladó levegö- és vízszennyezettségi értékek, megoldatlan hulladékeltakaríás, hogy csak a leglátványosabb elemeket említsük. A szegénység koncentrálódása, a városon belüli polarizáció és szegregáció hajtóerőket jelentenek a kriminalitás és erőszak terjedéséhez is, melyek a legnagyobb városokban jelentkeznek a legkritikusabb mértékben. Az alulfejlettségnek mindezen tünetei halmozottan jelentkeznek, ezáltal önerősítő ördögi köröket alakítanak ki, melyekböl pusztán a piaci folyamatok és az esetleges gazdasági növekedés következtében nem tudnak kitörni az érintett csoportok.

A fejlödő országok politikusai, kormányzatai - szinte minden ország esetében tudatában vannak az országuk torz városi struktúrájából adódó kedvezőtlen hatásoknak (GUO 2007), ugyanakkor többnyire nem megfelelően kezelik a kialakult helyzeteket. Közvetlen beavatkozásokkal, rövid távon a kedvezőtlen következmények kezelését célozzák meg az okok hosszú távú megszüntetése helyett. Ezzel nézetünk szerint a rendelkezésre álló szükös pénzügyi erőforrásaikat nem hatékonyan használják fel, és gyakran nem a problémák enyhítését, hanem fokozódását eredményezik. Jó példa erre az egyiptomi eset, ahol a kormányzat szatellit városok mesterséges alapításával kívánta csökkenteni Kairó nagyvárosi régiójának domi- 
nanciáját és a gyors népességnövekedésböl származó súlyosbodó nyomást (pressing problems). A hetvenes években inditott kísérlet kudarcát jól jelzi, hogy a hat újonnan alapitott város kihasználtsága a tervezett kapacitásokhoz képest az ezredfordulóra sem érte el a 8\%-ot (Yousry-Atta 1997). Továbbá a kormányzati ösztönzök által mesterségesen létrehozott új városokban található munkahelyekre nem ritkán Kairó fövárosi térségéböl ingáznak a munkavállalók, tovább növelve ezáltal a közlekedési rendszer túlterheltségét.

A szakirodalomban található esettanulmányokból számos, a fentihez hasonló „mismanagement"-et lehet találni. Ilyenek például, amikor a nyomornegyedek infrastrukturális ellátottságát politikai nyomásra jelentős közkiadások árán javítja a központi kormányzat, de gyakran a használati díjak sikertelen beszedése, valamint a jogi szabályozás megreformálásának hiányában az ott jellemző informális tevékenységek adóbevételeinek kiesése jelentős hiányokat okoznak a költségvetés bevételi oldalán. Ezt akár „fiskális parazitizmusnak” is nevezhetnénk.

A leírt példák azonban nem egyiptomi sajátosságok, hanem sokkal inkább a fejlödö országokra jellemző kormányzati kudarc, mely a korábban bemutatott piaci kudarccal párosulva az urbanizációs válság mélyülését vetíti elöre.

\section{Urbanizációs válság}

Mindezek tükrében írásunk végén kifejtjük, hogy mit is értünk az urbanizációs válság alatt. Az egy komplex jelenség, amely tartalmazza a városi túlzsúfoltságból adódó gazdasági, társadalmi hatékonyságveszteségeket és környezeti problémákat is, melyek rövid és hosszú távon egyarảnt, valamint mind mikro-, mind makroszinten súlyos következményekkel járnak a tágan értelmezett fejlődés tekintetében.

A gazdaság fejlettségi szintjéhez képest túlzott földrajzi koncentráció miatt fellépő legfontosabb negatív következmények a túlzsủfolt infrastruktúra (nem megfelelö közlekedési és közszolgáltatási kapacitások és alacsony minőségú szolgáltatások), környezetszennyezés, nem megfelelö életkörülmények (lakhatás, humán tőke minösége, egészségügyi körülmények), rossz közbiztonság (kriminalitás, eröszak) és az informális szektor ${ }^{9}$ térnyerése. Továbbá ide szokták sorolni a földhasználat és a közpénzügyek kérdéseit is. Ezek mind érintik a lakosság mindennapi életvitelét, de a gazdasági szereplök tevékenységeit is befolyásolják mind közvetlen, mind közvetett hatásokkal. Nézetünk szerint az urbanizációs válság kezelésekor kiemelt figyelmet kell fordítani a városi szegényekre, akik a legsérülékenyebbek a felsorolt negativ következmények kihívásaival szemben. Ehhez az új fejlesztéspolitikai alapelveknek megfelelöen képessé kell tenni őket a saját helyzetük javitására (enabling), és fel kell hatalmazni (empowerment) öket az önálló megoldások keresésére, megvalósítására, valamint a politikai döntéshozatalban való részvételre (participation).

Az urbanizációs válság nem koncentrálódik a fejlődő országok legnagyobb vảrosaira, de ott a legszembetünőbbek a jegyei, hiszen a hiányosságok, kudarcok mérete és halmozódása sokkal nagyobb mérteket ölt, és több embert érint. Ugyanakkor 
kiterjedhet a lényegesen kisebb, de a gazdasági és kormányzási kapacitásainál gyorsabban növekvő településre is.

Az urbanizációs válság mindezek alapján egy sokarcú jelenség, melynek részletes bemutatása egy újabb tanulmány témája lehet, de a teljesség igénye nélkül az tartalmazza az alábbi dimenziókat:

- demográfiai (a legnagyobb városokban való koncentrálódás kor és nem szerinti szelekciója);

- társadalmi (átalakuló életvitel, szegénység városiasodása, városok közötti és városon belüli polarizáció, szegregáció);

- gazdasági (átalakuló agglomerációs elönyök és hátrányok, foglalkoztatási és szektoriảlis kérdések, egyre komplexebbé váló telephelyválasztási döntések);

- környezeti (víz- és levegőszennyezés, hulladékgazdálkodás, helyi ökoszisztémák, épített környezet);

- strukturális (térbeli kiterjedés, szuburbanizáció, városhálózatok, kis és közepes, valamint legnagyobb városok közötti divergens fejlödés);

- politikai (kormányzási és közmenedzsment kérdések, közszolgáltatások és infrastrukturális beruházási döntések, intézményi és költségvetési) dimenziók.

Láthatjuk, hogy az urbanizációs válság különböző dimenziói mind párhuzamba állíthatók az új fejlödési paradigma ${ }^{10}$ összetevőivel, valamint itt is jellemzők az egyes tényezők összefüggése, a negatív externáliák interakcióiból kialakuló önerősítő körök. Mindezek az alulfejlettség újratermelödő köreihez vezethetnek, melyek kezelése egyre nagyobb terhet ró a helyi kormányzatok és a központi kormányzat számára. Épp ezért egyre nagyobb a nyomás a tartós megoldások keresése iránt, mely az okokat szünteti meg, és nem a következményeket kezeli. A bemutatott urbanizációs trendek tükrében az urbanizációs válság menedzselése jelenti az egyik legnagyobb politikai kihívást a jövőben a fejlödö országok kormányzatai számára.

\section{Következtetések}

Összegzésképpen elmondható, hogy a 2030-ig szóló előrejelzések szerint a világ népességének növekedése a fejlődő országok városi területeire fog koncentrálódni. Ezen növekedés föként az ázsiai és afrikai városokat érinti majd, és csak kisebb mértékben a latin-amerikai és karibi térséget. Ez utóbbi országokban ugyanis az urbanizációs folyamatok nagy része 1950-2000 között lezajlott.

Bár nézetünk szerint jelentősége alapján az alkalmazandó gazdaságpolitikák számára megfogalmazható normatív ajảnlások meghatározása meghaladja az itt rendelkezésre álló kereteket, nem éreznénk teljesnek tanulmányunkat néhány végkövetkeztetés megállapítása nélkül.

A fejlődő országokban megfigyelhető urbanizációs válság kialakulásában éppúgy közrejátszottak gazdasági, mint politikai hajtóerők. Az óriásvárosi koncentrációk hátterében milliónyi, mikro-szinten racionális döntés áll, melyek azonban makroszinten nem kívánatos eredményekhez vezetnek. Ezen döntések közvetlen befolyá- 
solása, a választási (pl. vándorlási, letelepedési) szabadság korlátozása nem jelent hatékony választ a kihívásokra, és a fejlődés új paradigmája tükrében nem is releváns opció. A kormányzatoknak a legnagyobb városi koncentrálódás irányába ható politikai ösztönzök csökkentését, megszüntetését kell célozniuk, és ez tartalmaz intézményi, politikai-közigazgatási, közmenedzsment reformokat is. Ezzel párhuzamosan a kisebb városok és a vidéki területek fejlődése előtt álló gazdasági és politikai akadályok csökkentése is elősegítheti a legnagyobb városi koncentrációkra nehezedő nyomás csökkentését. Szükséges azonban egy szemléletváltás is, amenynyiben a beavatkozások során nem a gazdasági növekedés, illetve annak erỏltetése kell, hogy célként szolgáljon, hanem a tágan értelmezett gazdaságilag és társadalmilag fenntartható, környezettel kompatibilis fejlödés, amely érvelésünk szerint egy kiegyenlítettebb területi struktúra felé való elmozdulást is tartalmaz.

$\mathrm{Az}$ urbanizációt jelen tanulmányunkban többnyire a városi népesség szintje, növekedési üteme és térbeli elhelyezkedése, valamint a városi méretek szerinti eloszlása tekintetében vizsgáltuk. A teljes képhez a népesség koncentrálódása mellett legalább ilyen fontos a gazdasági tevékenységek térbeli tömörülésének vizsgálata, azaz a foglalkozatás, a GDP-hez való hozzájárulás, a jövedelmi szintek figyelembe vétele is. Ezek további kutatási irányokat jeleznek.

\section{Jegyzetek}

${ }^{1}$ United Nation Population Division - UNPD.

${ }^{2}$ A következő fejezetben foglalkozunk részletesebben a vărosméretből adódó problémákkal, és utalunk rá, hogy nem csak a méret számít.

${ }^{3}$ Ez utóbbiról lásd bővebben Sassen $(2000 ; 2002)$ írásait, melyek ismertetésére itt nem térünk ki.

4 Itt érdemes megjegyezni, hogy egyes szerzők a londoni vagy párizsi agglomerációk túlsúlyát is a történelmi hagyatékra, konkrétan az ókori római birodalom által kialakított struktúrákra vezetik vissza.

5 Jó összefoglalảst ad erröl a Handbook of Regional and Urban Economics 2. kötetének 23. fejezete (Henderson 1987).

${ }^{6}$ Nem véletlenül nevezi Krugman és Livas birodalom nélkuili Rómáknak (,Romes without empire”) a fejlődő országok legnagyobb városait (Krugman-Livas 1996, 139).

${ }^{7}$ Elsőként Lipton (1976) nevéhez füződik a városi torzítások vizsgálata és elméleti megalapozása.

${ }^{8}$ Ld. az előző fejezetben említett optimális versus hatékony városméret vitát, valamint Capello és Camagni (2000) írását.

${ }^{9}$ Az informális szektor szerepéról bóvebben $\mathbf{I}$. de Soto (2000) és Todaro-Smith (2003) irásait. Itt arra utalunk csupán, hogy annak megitélése korántsem egyértelmúen negatív a városi szegények szemszögéból.

10

Ehhez l. bővebben Sen (2003) és Ricz (2005) írásait.

\section{Irodalom}

Ades, A.F.-Glaeser, E.L. (1995) Trade and Circuses: Explaining Urban Giants. - The Quarterly Journal of Economics. 1. 195-227. o.

Brutzkus, E. (1975) Centralized versus Decentralized Pattern of Urbanization in Developing Countries: An Attempt to Elucidate a Guideline Principle. - Economic Development and Cultural Change. 4. 633-652. o. 
Ricz Judit : Urbanizáció a fejlődő országokban: Trendek, dimenziók és kihívások

Tér és Társadalom 21. évf. 2007/3. 167-186. p.

Capello, R.-Camagni, R. (2000) Beyond Optimal City Size: An Evaluation of Alternative Urban Growth Patterns. - Urban Studies. 9. 1479-1496. o.

Cohen, B. (2004) Urban Growth in Developing Countries: A Review of Current Trends and a Caution Regarding Existing Forecasts. - World Development, 1. 23-51. o.

Cohen, B. (2006) Urbanization in Developing Countries: Current Trends, Future Projections, and Key Challenges for Sustainability. - Technology in Society. 28. 63-80. o.

de Soto, H. (2000) The mystery of capital: why capitalism triumphs in the West and fails everywhere else. Basic Books, New York.

Epstein, T.S.--Jezeph, D. (2001) Development - There is Another Way: A Rural-Urban Partnership Development Paradigm. - World Development. 8. 1443-1454. o.

Fay, M.-Opal, C. (2000) Urbanization without Growth: A Not-So-Uncommon Phenomenon. World Bank Policy Resaerch Working Paper 2412, Washington D.C.

GUO (2007) Global Urban Observatory Database. United Nations Habitat. Letöltve: http://www.unhabitat.org/programmes/guo/guo_analysis.asp.

Hamer A.M. (1994) Economic impacts of third world mega-cities: Is size the issue? - Fuchs, R.J.Brennan, E.-Chamie, J.-Lo, F.-Uitto, J.I. (eds.) Mega-city growth and the future. United Nations University Press, Tokyo.

Hamer, A.M.-Linn, F.JF. (1987) Urbanization in developing world: patterns, issues and policies. - Mills, E.S. (ed.) Handbook of Regional and Urban Economics. 2. Urban Economics. North-Holland, Amsterdam, New York-Oxford-Tokyo. 1255-1284. o.

Henderson, V. (1974) The Sizes and Types of Cities. - American Economic Review. 64. 640-656. o.

Henderson, V. (1987) General equilibrium modeling of systems of cities. - Mills, E.S. (ed.) Handbook of Regional and Urban Economics. 2. 927-956.0.

Henderson, V. (2000) How Urban Concentration Affects Economic Growth. World Bank Policy Research Working Paper 2326.

Henderson, V. (2002) Urbanisation in Developing Countries. - The World bank Research Observer. 1. 89-112. 0.

Jefferson, M. (1939) The Law of the Primate City. - Geographical Review. 29. 226-232. o.

Kasarda, J.D.-Crenshaw, E.M. (1991) Third World Urbanization: Dimensions, Theories and Determinants. - Annual Review Sociology. 17. 467-501. o.

Krugman, P.-Livas, E. (1996) Trade Policy and Third World Metropolis. - Journal of Development Economics. 49. 137-150. o.

Krugman, P. (2000) A földrajz szerepe a fejlödésben. - Tér és Társadalom. 4. 1-21. o.

Lipton, M. (1976) Why poor people stay poor; urban bias in world development. Harvard University Press, Cambridge.

Marshall, A. (1890 [1938]) Principles of Economics: an introductory volume. Porcupine Press, Philadelphia.

Megacity Challenges: a stakeholder perspective. (2007) www.siemens.com/megacities

Moomaw, R.L.-Alwosabi, M.A. (2003) An Empirical Analysis of Competing Explanations of Urban Primacy: Evidence from Asia and the Americas. Center for European Integration Studies, Working Paper Series B03-19.

Overman, H.G.-Venables, A.J. (2005) Cities in the Developing World. CEP Discussion Paper No. 695. Centre For Economic Performance (London School of Economics and Political Science), London.

Puga, D. (1996) Urbanisation patterns: European vs. less developed countries. Centre for Economic Performance, Discussion Paper No. 305.

Ricz J. (2005) Paradigmaváltás a fejlỏdés-gazdaságtanban. - Competitio. 2. 109-123. o.

Ricz J. (2007) Az agglomerálódás klasszikus és új logikája.-Külgazdaság. 7-8. Megjelenés alatt.

Sassen, S. (2000) Cities in a world economy. Thousand Oaks, California.

Sassen, S. (ed.) (2002) Global networks, linked cities. Routledge, New York, London.

Sen, A. (2003) Fejlödés mint szabadság. Európa Könyvkiadó, Budapest.

Todaro, M.P.-Smith, S.C. (2003) Economic Development. Oxford University Press, Oxford.

UNPD (2004) World Urbanization Prospects: The Revision 2003. United Nations Department of Economic and Social Affairs, Population Division. New York.

UNPD (2006) World Urbanization Prospects: The 2005 Revision. United Nations Department of Economic and Social Affairs, Population Division. New York.

Venables, A.J. (2005) Spatial disparities in developing countries: cities, regions and international trade. Jurnal of Economic Gepgraphy. 5. 3-21. o.

Williamson, J.G. (1965) Regional Inequality and the Process of National Development. - Economic Development and Cultural Change. 13.3-45. o. 
Williamson, J.G. (1988) Migration and Urbanization.-- Chenery, H.-Srinivasan, T.N. (eds.) Handbook of Development Economics. 1. Elsevier Science Publishers. 425-465. o.

Yousry, M.-Atta, T.A. (1997) The challenge of urban growth in Cairo. - Rakodi, C. (ed.) The urban challenge in Africa: Growth and management of its large cities. United Nations University Press, Tokyo.

Yusuf, S. (ed.) (2000) World Development Report: Entering the 21st century. World Bank, Oxford University Press, Oxford. 